ARTICLE

Received 23 Sep 2014 | Accepted 18 Nov 2014 | Published 20 Jan 2015

DOI: $10.1038 /$ ncomms 6879

\title{
Total synthesis of periploside $A$, a unique pregnane hexasaccharide with potent immunosuppressive effects
}

Xiaheng Zhang ${ }^{1}$, Yu Zhou ${ }^{2}$, Jianping Zuo ${ }^{2} \&$ Biao Yu ${ }^{1}$

Periploside $A$ is a pregnane hexasaccharide identified from the Chinese medicinal plant Periploca sepium, which features a unique seven-membered formyl acetal bridged orthoester (FABO) motif and potent immunosuppressive activities. Here, we show the synthesis of this molecule in a total of 76 steps with the longest linear sequence of 29 steps and $9.2 \%$ overall yield. The FABO motif is constructed via a combination of Sinaÿ's and Crich's protocol for the formation of orthoester and acetal glycosides, respectively. The 2-deoxy- $\beta$-glycosidic linkages are assembled stereoselectively with judicious choice of the glycosylation methods. The epimer at the spiro-quaternary carbon in the FABO motif has also been elaborated in a stereo-controlled manner. This epimer, as well as the synthetic analogues bearing the FABO motif, retain largely the inhibitory activities of periploside $A$ against the proliferation of T-lymphocyte, indicating the importance of the chemical connection of the FABO motif to their immunosuppressive activity.

\footnotetext{
${ }^{1}$ State Key Laboratory of Bioorganic and Natural Products Chemistry, Shanghai Institute of Organic Chemistry, Chinese Academy of Sciences, 345 Lingling Road, Shanghai 200032, China. ${ }^{2}$ State Key Laboratory of New Drug Research, Shanghai Institute of Materia Medica, Chinese Academy of Sciences, Shanghai 201203, China. Correspondence and requests for materials should be addressed to B.Y. (email: byu@mail.sioc.ac.cn).
} 
eriploside A (or Periplocoside E) is the prototypical member of a group of pregnane glycosides isolated from Periploca sepium and P. forrestii (Asclepiadaceae), which features a unique seven-membered formyl acetal bridged orthoester (FABO) linkage between two sugar units ${ }^{1-7}$. This natural product shows immunosuppressive activities, that is, it inhibits the ConA-induced $\mathrm{T}$ cell proliferation as potently as rapamycin and cyclosporin $\mathrm{A}$ while showing reasonably low toxicity $\left(\mathrm{IC}_{50}=0.64 \mu \mathrm{M} \text { and } \mathrm{CC}_{50}=10.1 \mu \mathrm{M}\right)^{5,6}$. The immunosuppressive effects of periploside $\mathrm{A}$ has also been found significant in mice models ${ }^{8-10}$, that validates the folkloric reputation of the plant as a traditional Chinese medicine for rheumatoid arthritis ${ }^{11}$. Such autoimmune diseases as rheumatoid arthritis, multiple sclerosis, systemic lupus erythematosus and Crohn's disease, are notoriously malignant and refractory, thus efficacious new immunosuppressant drugs have long been a quest $^{12}$.

The FABO motif in periplosides, which has been found critical to their activities ${ }^{6}$, remains ambiguous in both the chemical connection and stereochemistry for over two decades. In 1987, Hikino et al. reported the first structural assignment of periploside $\mathrm{A}$, in that the connection of the orthoester was proposed on the basis of extensive chemical degradation and spectroscopic analysis ${ }^{1}$. However, the stereochemistry of the quaternary anomeric carbon was overlooked but drawn in a configuration comprising an unusual $\alpha$ - $(1 \rightarrow 4)$-glycosidic linkage (1a). Shortly afterwards, Itokawa et al. ${ }^{2-4}$ suggested a novel peroxy linkage (1b) for periplosides (and named as periplocosides), as misled by a conventional colour reaction of peroxides, although all the analytical data of periplocoside E were found identical to those of the previous periploside A (ref. 3). This peroxide structure was then accepted till 2011 (refs 5,6),
Zhao and coworkers acquired an X-ray diffraction of a single crystal of a periploside congener, confirming the originally assigned FABO connection ${ }^{6}$. Unfortunately, the stereochemistry of the spiro-quaternary carbon remained incorrect until we examined it carefully during our journey toward the synthesis of periploside A (ref. 7).

Herein, we report the first total synthesis of periploside A (1), employing total of 76 steps of transformations from glucal, methyl $\alpha$-D-glucopyranoside and dehydroepiandrosterone, with the longest linear sequence of 29 steps and in $9.2 \%$ overall yield. The stereoselective construction of the FABO motif with either the natural or unnatural configuration at the anomeric spiroquaternary center is achieved via alternative combination of Crich's protocol for acetal glycoside synthesis and Sinaÿ's protocol for glycosyl orthoester formation. The 2-deoxy- $\beta$ glycosidic linkages are synthesized by glycosylation with trifluoroacetimidate donors $(\mathbf{6 / 2 7})$ equipped with 2-iodide, with digitoxosyl ortho-alkynylbenzoate donor (8) installed with bulky TBDPS group on the remote 3,4-OH, and with cymarosyl orthoalkynylbenzoate donor (2) under the promotion of $\mathrm{Ph}_{3} \mathrm{PAuOTf} /$ TTBP. In addition, a preliminary structure-activity relationship of the synthetic periplosides against the proliferation of T-lymphocyte is provided, indicating the importance of the chemical connection of the FABO motif to the activities.

\section{Results}

Retrosynthetic analysis. Given the big size and linear structure of the target molecule, a convergent synthesis was desired ${ }^{13}$. Thus, periploside A (1) was disconnected into two fragments of similar complexity, that is, tetrasaccharide donor 2 and pregnane FABO disaccharide 3 (Fig. 1). The $(1 \rightarrow 4)$-cymarosyl linkage between

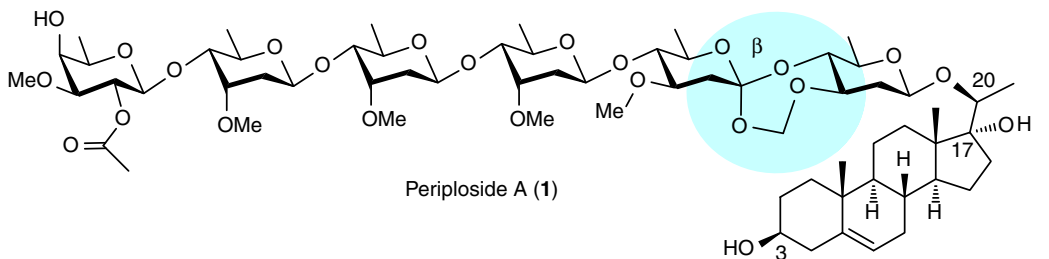

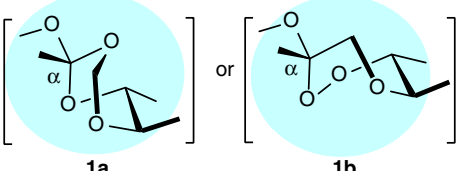

$1 \mathrm{a}$

1b
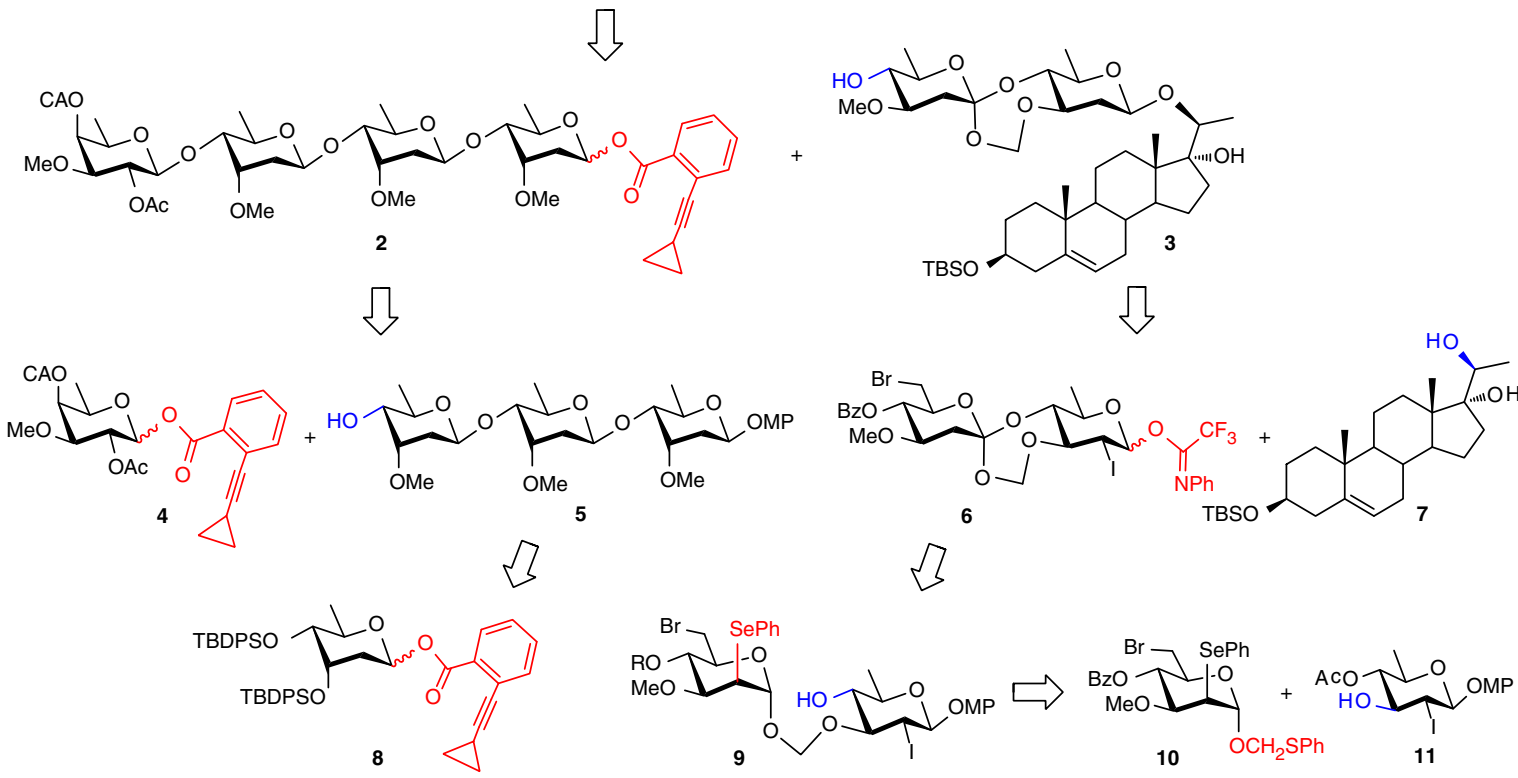

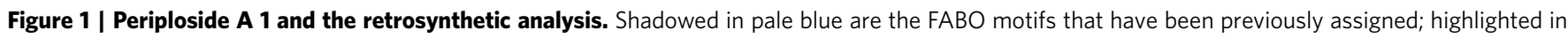
red are leaving groups in donors and in blue are hydroxyl groups in acceptors. Ac, acetyl; CA, chloroacetyl; MP, 4-methoxyphenyl; TBDPS, tertbutyldiphenylsilyl; TBS, tert-butyldimethylsilyl. 
the tetrasaccharide unit and $\mathbf{3}$ would be difficult to construct in favour of formation of the thermodynamically unfavored $\beta$ anomer ${ }^{14-17}$; the glycosylation protocol with orthoalkynylbenzoates as leaving groups (as in 2) under the catalysis of a gold(I) complex could address this problem, in that substitution via an $\alpha$-glycosyloxypyrylium or $\alpha$-triflate intermediate might get invoked ${ }^{18}$. The $\beta-(1 \rightarrow 4)$-cymarosyl linkages in tetrasaccharide 2 , however, could be built stereoselectively under the influence of a substituent at the axial 3-OH of a digitoxosyl donor, which could subsequently be converted into the required methyl group. In this respect, we had screened carefully during the synthesis of digitoxin and gordonoside $\mathrm{F}$ and found gold(I)-catalysed glycosylation with digitoxosyl ortho-cyclopropylethynylbenzoate equipped with two bulky TBDPS groups at 3,4-OH (that is, 8) to be an optimal choice ${ }^{15,17}$. After furnishing the cymarose trisaccharide $\mathbf{5}$, its coupling with the terminal digitalose unit could be realized with donor 4 , in that the formation of the $\beta$-linkage should be secured by participation of the 2-O-acetyl group; and the 4-O-chloroacetyl group was selectively removable afterwards. The $p$-methoxyphenyl (MP) group was employed throughout (as in 5,9 and 11) as the anomeric protecting group, which could remain intact before cleavage and subsequently converting the saccharides into donors (for example, $\mathbf{2}$ and $\mathbf{6}$ ).

Uncertainty lies in the synthesis of FABO disaccharide 3. Condensation of $3 \beta$-silyloxy-pregnene-17 $\alpha, 20 \alpha$-diol 7 with disaccharide trifluoroacetimidate $\mathbf{6}$, one of the most reliable type of glycosylation donors ${ }^{19}$, which was equipped with an equatorial iodide at C2 (ref. 20), would lead to the desired C20-O- $\beta$ glycoside 3 in a regio- and stereo- selective manner. However, few clues occur in the literatures, which could lead to the construction of a disaccharide precursor consisting of the FABO linkage. The most promising approach turned out to be a combination of Crich's protocol to form the formyl acetal glycosidic linkage (from a thiomethyl glycoside donor such as 10; ref. 21) and Sinaÿ's protocol to synthesize the anomeric orthoester via a ketene acetal intermediate (derived from a 2-selenoglycoside such as 9; refs 22-24). However, the tolerance of the formyl acetal (in 9) towards the strong conditions required for Sinaÿ's oxidationelimination-cyclization sequence and the stereochemistry in the formation of the seven-membered spiro-orthoester were beyond estimation.

Synthesis of tetrasaccharide donor 2. The desired digitalosyl and digtoxosyl ortho-cyclopropylethynylbenzoates $\mathbf{4}$ and $\mathbf{8}$ were prepared in a robust manner from D-fucose (13 steps and 37\% overall yield) (see Supplementary Methods) and methyl $\alpha$-Dglucopyranoside (10 steps and $47 \%$ overall yield) ${ }^{15}$, respectively. Subjection of $\mathbf{8}$ to glycosidation with $p$-methoxyphenol under optimized conditions ( 0.1 equivalent (equiv) $\mathrm{Ph}_{3} \mathrm{PAuNTf}_{2}$, toluene, $4 \AA$ molecular sieves (MS), $-40^{\circ} \mathrm{C}$ ) led to $\beta$-glycoside 12 as the sole anomer in an excellent 95\% yield (Fig. 2). Removal of the 3,4-di-O-TBDPS group followed by selective acetylation of the axial $3-\mathrm{OH}$ via orthoester formation/hydrolysis provided glycoside 13 bearing a free $4-\mathrm{OH}(92 \% \text {, two steps })^{25}$. Similar transformations were then applied to extend monosaccharide 13 to trisaccharide 17, in that the glycosidation of 8 with monosaccharide acceptor 13 and disaccharide acceptor 15 led to the corresponding coupled 2 -deoxy- $\beta$-saccharides nearly quantitatively. Trisaccharide $3^{\prime \prime}, 4^{\prime \prime}$-diol 17 was then subjected to a tin-mediated selective benzylation on the equatorial $4^{\prime \prime}-\mathrm{OH}$ (ref. 26); cleavage and scramble of the acetyl groups on the axial hydroxyl groups were detected, nevertheless, exposure of the resultant mixture to $\mathrm{LiOH}$ afforded $\mathbf{1 8}$ in excellent yield $(87 \%$, three steps). The three axial hydroxyl groups in $\mathbf{1 8}$ were then methylated (99\%). Unexpectedly, hydrogenolysis of the $4^{\prime \prime}-O-$ benzyl group in trisaccharide 19 under conventional conditions
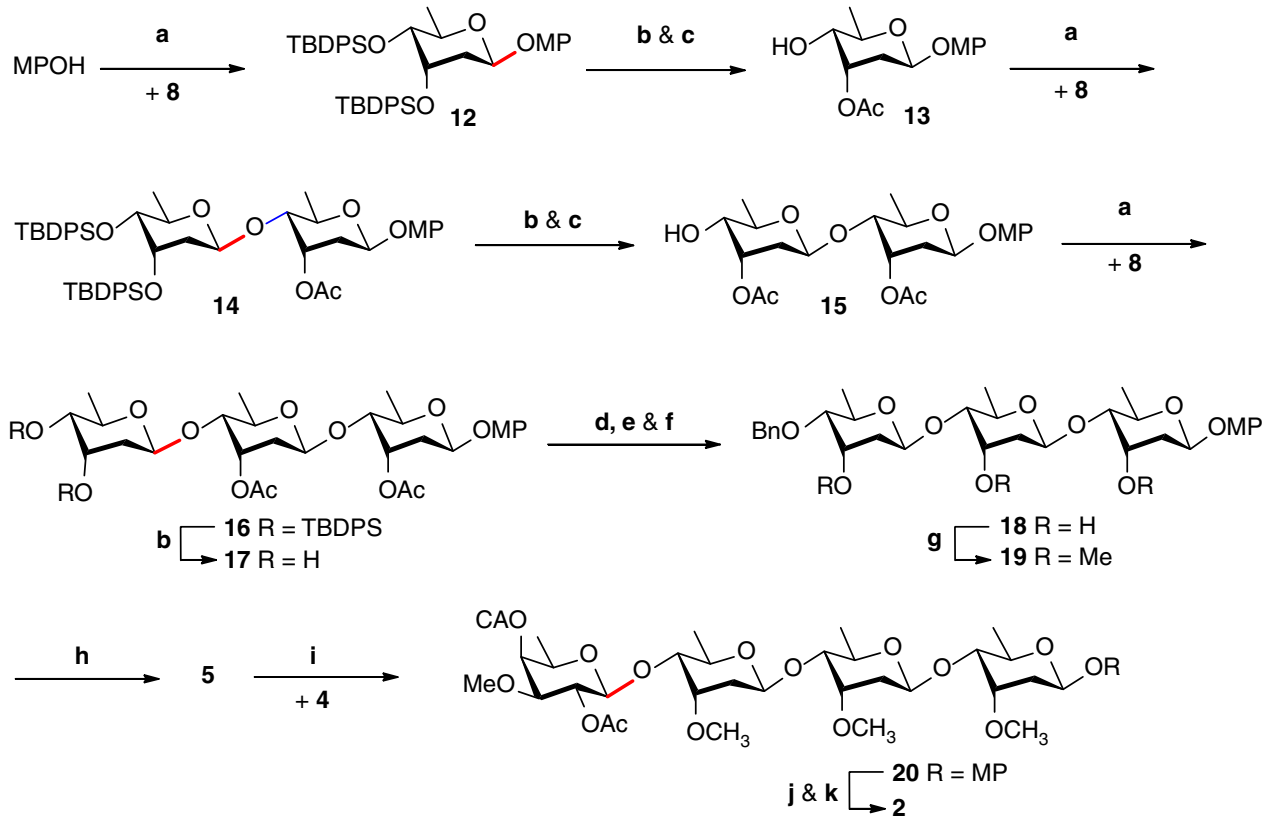

Figure 2 | Synthesis of tetrasaccharide donor 2. Highlighted in red are the nascent glycosidic bonds. (a) $\mathrm{Ph}_{3} \mathrm{PAuNTf} 2(0.1$ equiv), toluene, $4 \AA$ MS $-40{ }^{\circ} \mathrm{C} ; 95 \%$ and $\beta$ only (for 12); $99 \%$ and $\beta$ only (for $\mathbf{1 4}$ and 16); (b) TBAF, THF, $0^{\circ} \mathrm{C}$ to RT; $99 \%$ (from 12); $94 \%$ (from 14); $96 \%$ (from 16);

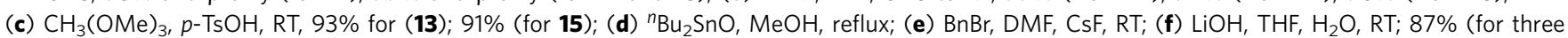
steps); (g) Mel, $\mathrm{NaH}, \mathrm{DMF}, 0^{\circ} \mathrm{C}$ to RT, 99\%; (h) $\mathrm{Pd}(\mathrm{OH})_{2} / \mathrm{C}, \mathrm{H}_{2}$ (1 atm), Et $3 \mathrm{~N}, \mathrm{EtOAc}, \mathrm{MeOH}, 50{ }^{\circ} \mathrm{C}, 93 \%$; (i) $\mathrm{Ph}_{3} \mathrm{PAuNTf}_{2}(0.2 \mathrm{equiv})$, toluene, $5 \AA$ MS, $-50{ }^{\circ} \mathrm{C}$ to RT, $93 \%, \beta / \alpha=4 / 1 ;(\mathbf{j}) \mathrm{Ag}(\mathrm{DPAH})_{2}, \mathrm{CH}_{3} \mathrm{CN}, \mathrm{H}_{2} \mathrm{O}, 0{ }^{\circ} \mathrm{C}$ to $\mathrm{RT}, 95 \%$; (k) o-cyclopropylethynylbenzoic acid, EDCl, DMAP, $4 \AA \mathrm{MS}, \mathrm{CH} \mathrm{Cl}_{2}$, RT, 99\%. DMAP, 4,4-dimethylaminopyridine; DPAH, bis(hydrogen dipicolinate); EDCl, $N$-ethyl- $N^{\prime}$-(3-dimethylaminopropyl)carbodiimide hydrochloride; MS, molecular sieves; TBAF, tetrabutylammonium fluoride. 
$\left(\mathrm{Pd}(\mathrm{OH})_{2} / \mathrm{C}, \mathrm{H}_{2}\right.$, room temperature $\left.(\mathrm{RT})\right)$ led to cleavage of the glycosidic linkages, testifying the vulnerability of the cymarosyl$\beta$ - $(1 \rightarrow 4)$-linkage. Thus, $\mathrm{Et}_{3} \mathrm{~N}$ was added to sequester any nascent proton; the hydrogenolysis proceeded sluggishly, nevertheless, leading to the desired trisaccharide $\mathbf{5}$ in a satisfactory $93 \%$ yield at $50{ }^{\circ} \mathrm{C}$ for 2 days.

Given the acid lability of the cymarosyl- $\beta-(1 \rightarrow 4)$-linkage, it was not fully surprising to find that glycosylation of trisaccharide acceptor 5 with digitalosyl donor 4 in the presence of $\mathrm{Ph}_{3} \mathrm{PAuOTf}$ led to considerable cleavage of the trisaccharide. $\mathrm{Ph}_{3} \mathrm{PAuNTf}_{2}$ was found to be more stable towards moisture (thus less acidic) ${ }^{27}$, therefore, it catalysed the condensation of 5 and 4 smoothly. However, in spite of the presence of 2-O-acetyl group in donor 4, the glycosylation led to anomeric mixtures of the coupled tetrasaccharide. Under optimized conditions $(0.2$ equiv $\mathrm{Ph}_{3} \mathrm{PAuNTf}_{2}$, toluene, $5 \AA \mathrm{MS},-50^{\circ} \mathrm{C}$ to $\left.\mathrm{RT}\right)$, tetrasaccharide 20 was obtained in $93 \%$ yield with $\beta / \alpha$ ratio of $4: 1$, which was separable on silica gel column chromatography. Removal of the anomeric MP group in tetrasaccharide $\mathbf{2 0}$ with CAN was not successful under a variety of conditions, resulting unavoidably degradation of the cymarosyl- $\beta$ - $(1 \rightarrow 4)$-linkages. Fortunately, a mild oxidizing agent, $\operatorname{Ag}(\mathrm{DPAH})_{2}$, could achieve this task $\left(\mathrm{CH}_{3} \mathrm{CN} / \mathrm{H}_{2} \mathrm{O}, \quad 0^{\circ} \mathrm{C}\right.$ to $\left.\mathrm{RT}\right)$ to afford smoothly the corresponding hemiacetal (95\%) (ref. 28), which was then subjected to the formation of ortho-cyclopropylethynylbenzoate 2 (99\%) (see Supplementary Methods).

Attempts at construction of the FABO motif. We have tried a number of approaches to the construction of the FABO disaccharide motif, those include condensation of sugar lactones with vicinal diols in the presence of formaldehyde or its surrogates 29,30 , transacetalation of sugar lactones with sugar 4-hydroxyl-3-methyoxymethyl ether derivatives ${ }^{31}$, and intramolecular hydrogen atom transfer reactions of formyl acetal linked disaccharides ${ }^{21,32,33}$. However, no coupled FABO products have ever been detected, that prompted us to focus our attention on the planned Crich-Sinaÿ approach (Fig. 3). Thus, starting from D-glucal triacetate, 3-O-methyl-6-bromo-glucal 21 and p-methoxyphenyl 2,6-dideoxy-2-iodo-glucoside 11 were prepared in seven steps (66\% overall yield) and 13 steps (18\% overall yield), respectively (see Supplementary Methods). Glucal 21 was converted into the desired phenylthiomethyl 2-phenylseleno- $\alpha$-D-mannopyranoside 10 in three steps (45\%), that is, addition with $\mathrm{PhSeCl}$ to provide 2-phenylseleno-Dmannopyranose 22, conversion of the lactol into fluoride with DAST, and subsequent glycosidation with $\mathrm{PhSCH}_{2} \mathrm{OH}$ in the presence of $\mathrm{SnCl}_{2}$ (refs 23,34). Condensation of $\mathbf{1 0}$ with sugar acceptor 11 under Crich's conditions (NIS, TfOH, $\mathrm{CH}_{2} \mathrm{Cl}_{2}$, $-30^{\circ} \mathrm{C}$ ) did lead to the desired acetal glycoside 24 , albeit in only a moderate yield of $\sim 30 \%$; the major product turned out to be the $\alpha$-glycoside 23 ( $\sim 65 \%)$. A wide variety of the promoters for glycosidation of thioglycosides ${ }^{35}$ were screened in the present coupling (see Supplementary Table 1), including $\mathrm{NBS} \mathrm{TfOH}^{36}$, $\mathrm{Tf}_{2} \mathrm{O} / \mathrm{BSP} / \mathrm{TTBP}^{37}$, DMTST/TTBP ${ }^{38}, \mathrm{MeOTf}^{39}$ and NIS/ $\mathrm{AgOTf}^{40}$. However, the yield of acetal glycoside $\mathbf{2 4}$ was not improved. These results indicate that the transient glycosyloxymethyl cation (generated from 10) decomposes favourably to the glycosyl oxocarbenium species (and a molecule of formaldehyde); capture of the oxocarbenium intermediate by the incoming hydroxyl group (in 11) leads to disaccharide 23. Adjustment of the substituting groups in donor 10, that is, removal of the 6bromide and/or replacement of the 4-O-benzoyl group with benzyl group also failed to improve the yields of the corresponding acetal glycosides in condensation with $\mathbf{1 1}$. Gratifyingly, when we applied the inverse procedure ${ }^{41}$ (addition of donor $\mathbf{1 0}$ to a mixture of the acceptor $\mathbf{1 1}$ and promoter NIS/ $\mathrm{TfOH}$ at $-30^{\circ} \mathrm{C}$ ) and increased the equivalent of acceptor 11 (to 5.0 equiv), acetal glycoside 24 was obtained in a satisfactory $75 \%$ yield. The 4 - $O$-acetyl and $4^{\prime}$-O-benzoyl group in $\mathbf{2 4}$ were removed simultaneously in the presence of $\mathrm{MeONa}$ in $\mathrm{MeOH}$, providing diol 9 (93\%), which was ready for Sinaÿ's orthoester formation.

Thus, 2'-seleno-disaccharide 9 was subjected to oxidation $\left(\mathrm{NaIO}_{4}, \mathrm{NaHCO}_{3}, \mathrm{MeOH} / \mathrm{CH}_{2} \mathrm{Cl}_{2} / \mathrm{H}_{2} \mathrm{O}, \mathrm{RT}\right)$ to provide the selenoxide cleanly, subsequent syn-elimination and intramolecular cyclization of the resultant ketene acetal (A) took place sluggishly under forced conditions (vinyl acetate/toluene/DIPA, $140{ }^{\circ} \mathrm{C}$ ), leading to an orthoester product (25) in a moderate $20 \%$ yield for $12 \mathrm{~h}$. By carefully screening the reaction conditions, we finally managed to obtain 25 in an excellent $85 \%$ yield under microwave irradiation $\left(145^{\circ} \mathrm{C}, 20 \mathrm{~min}\right)$. The addition of the 4-hydroxyl group onto $\mathrm{Cl}^{\prime}$ of the ketene acetal in $\mathbf{A}$ could proceed from both the top and the bottom faces, thus two diastereoisomers should be provided. Surprisingly, only one isomer (25) was isolated under various conditions. We had expected that the diastereoselectivity bestowed by the two sugar units could lead to formation of the native configuration in the natural product (opposite to that drawn in 25). However, in the previous synthesis of the Sinay-type five- and six-membered orthoesters, cyclization of the incipient ketene acetals was found to favour formation of the axial $\alpha$-linkage, so as to maximize the anomeric effect ${ }^{22-24}$ or to follow the trajectory of addition onto Woerpel's low-energy conformer of the dioxocarbenium intermediate $^{42,43}$. Determination of the configuration of the quaternary $\mathrm{C1}^{\prime}$ in $\mathbf{2 5}$ was not possible by spectroscopic methods, especially without comparison to its epimer, and attempts at acquisition of a single crystal of $\mathbf{2 5}$ or its derivatives for X-ray diffraction analysis were unsuccessful. Therefore, this problem was not solved until completion of the total synthesis.

Synthesis of $\mathbf{C 1}^{\prime \prime}$-epi-periploside A (31). Temporary protection of the $4^{\prime}-\mathrm{OH}$ in $\mathbf{2 5}$ with benzoyl group led to $\mathbf{2 6}$ (99\%), which was subjected to selective cleavage of the anomeric MP group ( $\mathrm{Ag}(\mathrm{D}$ $\left.\mathrm{PAH})_{2}, \mathrm{CH}_{3} \mathrm{CN}, \mathrm{H}_{2} \mathrm{O}, 90 \%\right)$ and subsequent formation of trifluoroacetimidate (95\%) to afford the desired donor 27 (Fig. 3). Glycosylation of pregnane diol 7, which was prepared from hydroxyandrost-5-en-17-one in three steps (see Supplementary Methods and Supplementary Fig. 59), with disaccharide imidate 27 proceeded smoothly under the catalysis of TBSOTf ( 0.1 equiv) in the presence of $5 \AA \mathrm{MS}$ at $-78{ }^{\circ} \mathrm{C}$ in $\mathrm{CH}_{2} \mathrm{Cl}_{2}$, affording pregnane 20 -O-disaccharide 28 in $85 \%$ (96\%, b.r.s.m.) yield and $\beta / \alpha$ ratio of $3: 1$. The erosion of 1,2-trans-selectivity in the glycosylation with a donor (that is, 27) equipped with an iodide at C2 could be contributed to the presence of the FABO motif, which might cause conformational restraint for the neighbouring participation. Notably, the present reaction must be quenched at $-78^{\circ} \mathrm{C}$ (with $\mathrm{Et}_{3} \mathrm{~N}$ ), so as to avoid the decomposition of the acid-labile FABO motif. Reductive removal of the bromide and iodide in $\mathbf{2 8}$ under the conventional radical conditions $\left(\mathrm{AIBN} / \mathrm{Bu}_{3} \mathrm{SnH}\right.$, toluene, $80^{\circ} \mathrm{C}$ ) led to decomposition of the substrate. $\mathrm{Et}_{3} \mathrm{~B}$ could initiate the radical reaction at $\mathrm{RT}^{44}$, which thus enabled the reduction of 28 with $\mathrm{Bu}_{3} \mathrm{SnH}$ to proceed smoothly to afford the corresponding deoxydisaccharide (99\%). Subsequent removal of the $4^{\prime}$-O-benzoyl group provided the desired pregnane 20-Odisaccharide 29 (99\%).

The expected challenge in stereoselective construction of the 2deoxy- $\beta$-cymarosyl- $(1 \rightarrow 4)$-linkage in the union of tetrasaccharide 2 and pregnane disaccharide $\mathbf{2 9}$ was further manifested by the fact that both the 2,6-dideoxyglycosidic linkages and the FABO motif were shown to be extremely labile toward acid. Thus, we screened carefully the coupling conditions, including the gold(I) 

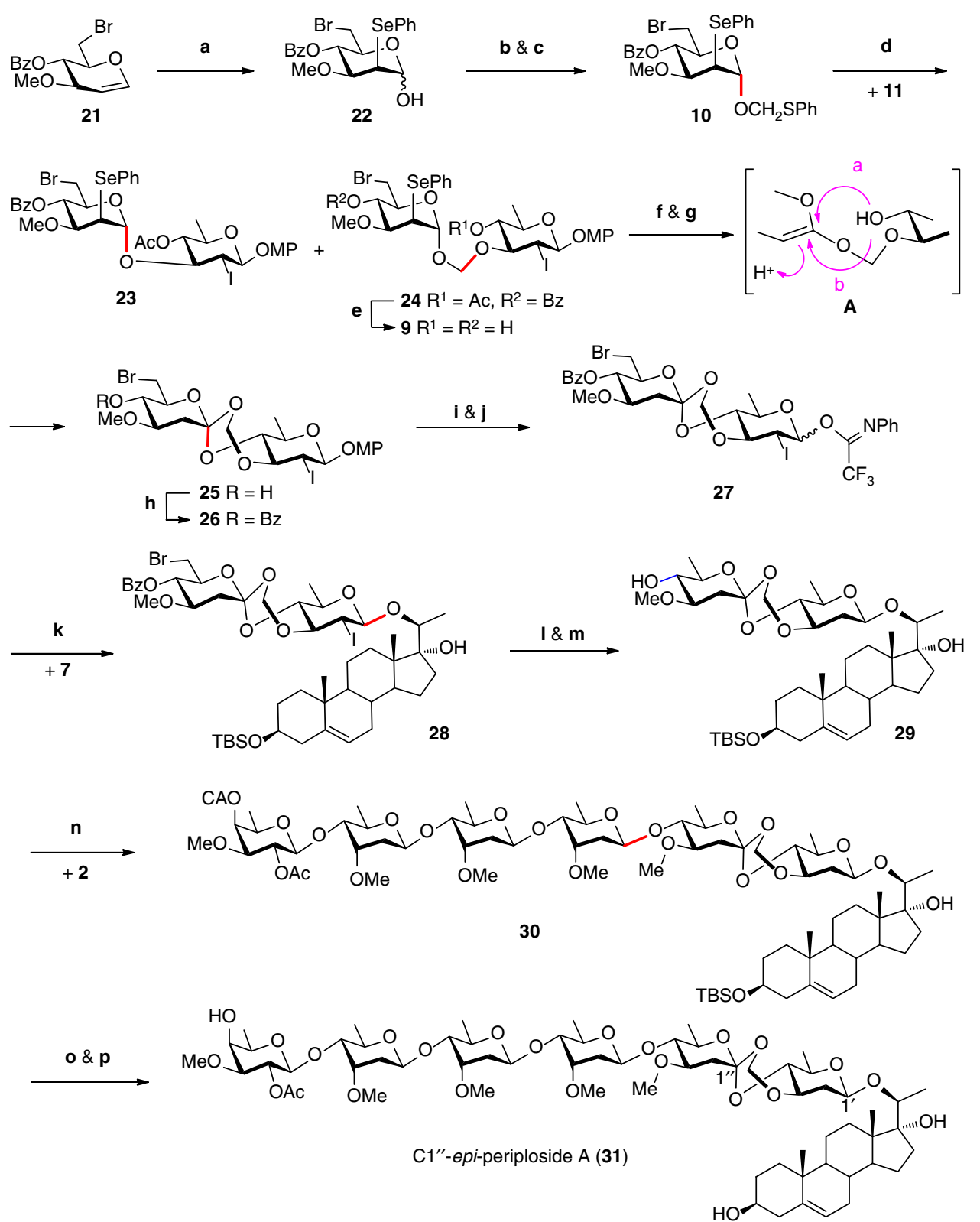

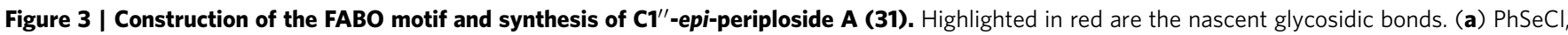
$\mathrm{CH}_{3} \mathrm{CN},-40{ }^{\circ} \mathrm{C}, 78 \%$; (b) DAST, THF, $-30^{\circ} \mathrm{C}$ to RT; (c) $\mathrm{PhSCH}_{2} \mathrm{OH}, \mathrm{SnCl}_{2}, \mathrm{CH}_{2} \mathrm{Cl}_{2}, 4 \AA \mathrm{MS},-40^{\circ} \mathrm{C}$ to RT; $58 \%$ (for two steps); (d) $\mathrm{NIS}, \mathrm{TfOH}$, $\mathrm{CH}_{2} \mathrm{Cl}_{2},-30^{\circ} \mathrm{C}, 75 \%$ (for 24), 20\% (for 23); (e) $\mathrm{MeONa}, \mathrm{MeOH}, \mathrm{CH}_{2} \mathrm{Cl}_{2}, \mathrm{RT}, 93 \%$; (f) $\mathrm{NalO}_{4}, \mathrm{NaHCO}_{3}, \mathrm{MeOH}_{2} \mathrm{CH}_{2} \mathrm{Cl}_{2}, \mathrm{H}_{2} \mathrm{O}, \mathrm{RT}, 99 \%$; (g) vinyl acetate, toluene, DIPA, $\mathrm{Mw}, 145^{\circ} \mathrm{C}, 20 \mathrm{~min}, 85 \%$; (h) $\mathrm{BzCl}, \mathrm{Et}_{3} \mathrm{~N}, \mathrm{DMAP}, \mathrm{CH}_{2} \mathrm{Cl}_{2}, 0^{\circ} \mathrm{C}$ to RT, 99\%; (i) $\mathrm{Ag}(\mathrm{DPAH}){ }_{2}, \mathrm{CH}_{3} \mathrm{CN}, \mathrm{H}_{2} \mathrm{O}, 0{ }^{\circ} \mathrm{C}$ to $\mathrm{RT}, 90 \%$; (j) N-phenyl-2,2,2-trifluoroacetimidoyl chloride, $\mathrm{Cs}_{2} \mathrm{CO}_{3}, \mathrm{CH}_{2} \mathrm{Cl}_{2}, \mathrm{RT}, 95 \%$; (k) TBSOTf, $\mathrm{CH}_{2} \mathrm{Cl}_{2}, 5 \AA \mathrm{MS},-78^{\circ} \mathrm{C}, 85 \%, \beta / \alpha=3 / 1 ;(\mathbf{I}) \mathrm{Et}{ }_{3} \mathrm{~B}, \mathrm{Bu}_{3} \mathrm{SnH}_{\text {, }}$ toluene, RT, 97\%; (m) MeONa, $\mathrm{MeOH}, \mathrm{CH}_{2} \mathrm{Cl}_{2}, \mathrm{RT}$, 99\%; (n) $\mathrm{Ph}_{3} \mathrm{PAuOTf}$ (0.8 equiv), TTBP, $\mathrm{CH}_{2} \mathrm{Cl}_{2}, 4 \AA \mathrm{MS},-20^{\circ} \mathrm{C}$ to $-10^{\circ} \mathrm{C}, 64 \%$ ( $87 \%$ b.r.s.m.), $\beta / \alpha=2.1 / 1$; (o) thiourea, pyridine, $\mathrm{EtOH}, 80^{\circ} \mathrm{C}$; (p) $\mathrm{HF} \cdot \mathrm{py}$, pyridine; $\mathrm{THF}, \mathrm{O}^{\circ} \mathrm{C}$ to RT; $91 \%$ (for two steps). DAST, (diethylamino)sulfur trifluoride; DIPA, diisopropylamine; TBSOTf, tert-butyldimethylsilyl trifluoromethane sulfonate; Mw, microwave; TTBP, 2,4,6-tri-tert-butylpyrimidine.

catalyst, solvent and temperature. When the coupling of $\mathbf{2}$ and $\mathbf{2 9}$ was conducted in the presence of $\mathrm{Ph}_{3} \mathrm{PAuNTf}_{2}$ ( 0.2 equiv), the coupled hexasaccharide was obtained in good yield (50\%) but in favour of the thermodynamically more stable $\alpha$-anomer $(\beta / \alpha \sim 1: 3)$. With $\mathrm{Ph}_{3}$ PAuOTf as the catalyst, however, the reaction of 2 and 29 provided a messy mixture. Careful isolation led to identification of a pentasaccharide lactone, which was derived from cleavage of the FABO linkage in the coupled hexasaccharide (30). Encouragingly, the originally formed cymarosyl- $(1 \rightarrow 4)$-linkage in the resultant pentasaccharide lactone was found in the required $\beta$ configuration, implying that the glycosylation reaction took place via a glycosyl $\alpha$-triflate intermediate $^{18}$. Nevertheless, the HOTf generated after glycosylation, before being quenched by the isochromen-4-yl gold(I) complex ${ }^{45}$, degraded the FABO linkage. On the basis of this rational, we introduced a hindered base, that is, 2,4,6-tri-tertbutylpyrimidine (TTBP), into the present $\mathrm{Ph}_{3} \mathrm{PAuOTf}$-catalysed glycosylation to rest the incipient HOTf, so as to avoid the cleavage of the FABO linkage. The sequester of the HOTf also retarded the gold(I) catalytic cycle, therefore, requiring almost equivalent of the gold complex to drive the reaction to completion $^{45,46}$. In fact, the condensation of 2 and 29 proceeded 
smoothly in the presence of $\mathrm{Ph}_{3}$ PAuOTf ( 0.8 equiv) and TTBP (1.5 equiv) in $\mathrm{CH}_{2} \mathrm{Cl}_{2}$ at $-10^{\circ} \mathrm{C}$, leading to the coupled hexasaccharide 30 in a satisfactory yield of $64 \%(87 \%$, b.r.s.m.) and $\beta / \alpha$ ratio of 2.1:1. Finally, removal of the terminal CA group and TBS group was achieved with thiourea ${ }^{47}$ and pyridinebuffered HF-pyridine, respectively, furnishing the target pregnane hexasaccharide 31 cleanly (91\%, two steps).

The ${ }^{1} \mathrm{H}$ and ${ }^{13} \mathrm{C}$ NMR spectra of $\mathbf{3 1}$ are similar to those of the authentic periploside A (1) (see Supplementary Figs 60 and 61). However, discrepancies occur for the signals from the formyl acetyl $\mathrm{CH}_{2}$ residue (88.4 p.p.m. for the ${ }^{13} \mathrm{C}$ signal in 31 versus 86.4 p.p.m. in 1; 4.93 and 4.82 p.p.m. for the ${ }^{1} \mathrm{H}$ signals in $\mathbf{3 1}$ versus 5.13 and 4.74 p.p.m. in $\mathbf{1}$ ) (see Supplementary Table 3). In addition, the adjacent $\mathrm{C}^{\prime}, \mathrm{C}^{\prime \prime}$ and $\mathrm{C}^{\prime \prime}$ are also in disparate chemical shifts $\left(\mathrm{C}^{\prime}\right.$ : 81.5 versus 79.2 p.p.m.; $\mathrm{C}^{\prime \prime}: 37.9$ versus 36.7 p.p.m.; C $3^{\prime \prime}$ : 77.4 versus 78.3 p.p.m., in 31 and 1, respectively). These discrepancies indicate that the synthetic $\mathbf{3 1}$ is indeed the epimer of periploside A (1) with the opposite configuration at the quaternary $\mathrm{C1}^{\prime \prime}$. The problem of diastereoselectivity in the previous formation of the FABO motif is thus addressed.

Construction of the FABO motif of the natural configuration. The addition of the hydroxyl group onto the ketene acetal in $\mathbf{A}$ proceeded exclusively from the $\alpha$ face, leading to the FABO disaccharide with the unnatural configuration $(\mathbf{9} \rightarrow \mathbf{2 5})$. The presence of a nucleophile capable of interception of the oxocarbenium species developed from the ketene acetal might lead to a thermodynamically favored $\alpha$-intermediate; substitution of the intermediate in situ by the 4-hydroxyl group would then proceed from the $\beta$ face to provide the FABO disaccharide with the natural configuration. Therefore, we tried the elimination/cyclization (from 9) in various nucleophilic solvents, including $\mathrm{CH}_{3} \mathrm{CN}$, 1,4-dioxane, THF, DME, DMF and $\mathrm{MeOH}$, under varied temperatures; however, the only $\mathrm{FABO}$ disaccharide identified was 25. Addition of nucleophilic additives, such as 4-dimethylaminopyridine (DMAP), $\mathrm{LiBr}, \mathrm{NaBr}$ and $\mathrm{NaI}$, was also found futile. The presence of an electrophilic reagent, such as NIS, NBS and $\mathrm{I}_{2}$, might convert the ketene acetal into a 1,2-halonium intermediate, which could then be attacked by the 4-hydroxyl group to give the FABO disaccharide. These attempts were again unsuccessful.

The failure in formation of the seven-membered orthoester in the desired stereochemistry forced us to construct the orthoester before cyclization of the formyl acetal (Fig. 4). Thus, 2phenylseleno-D-mannopyranoside $\mathbf{2 2}$ was converted into the fluoride (with DAST), which was then coupled with sugar acceptor 32 (see Supplementary Methods) under the action of $\mathrm{SnCl}_{2}$ to give $\alpha$-disaccharide 33 (85\%). Gratifyingly, after intensive attempts, we managed to obtain the ketene acetal $\mathbf{3 4}$ in excellent yield (91\%) from disaccharide 33 via selenoxide formation and syn-elimination under the modified Sinaÿ conditions $\left(\mathrm{NaIO}_{4}, \mathrm{NaHCO}_{3}, \mathrm{MeOH} / \mathrm{CH}_{2} \mathrm{Cl}_{2} / \mathrm{H}_{2} \mathrm{O}, \mathrm{RT}\right.$; then vinyl acetate/toluene/DIPA, microwave $140{ }^{\circ} \mathrm{C}, 40 \mathrm{~min}$ ). Although purification of $\mathbf{3 4}$ on silica gel required the addition of $1 \% \mathrm{Et}_{3} \mathrm{~N}$ in the eluent to prevent hydrolysis, the purified ketene acetal 34 remained stable at $-20^{\circ} \mathrm{C}$ for several days. To the best of our knowledge, this is the first time a ketene acetal linked disaccharide (that is, 34) being isolated. Noteworthy is the decisive role played by the 3-O-Lev group (in 33-35), which facilitated the procurement of the ketene acetal disaccharide as well as the selective removal afterwards; in contrast, analogues of 33 bearing an electron-donating group (for example, TBS) at the $3-\mathrm{OH}$ led to decomposed monosaccharide derivatives under identical conditions.

Addition of $\mathrm{PhSCH}_{2} \mathrm{OH}$ onto ketene acetal 34 was first attempted in $\mathrm{CDCl}_{3}$ at $50^{\circ} \mathrm{C}$ (ref. 48), the starting ketene acetal decomposed largely in $12 \mathrm{~h}$, with the desired orthoester being isolated in low yield (20\%) as a single $\alpha$-isomer. By raising the
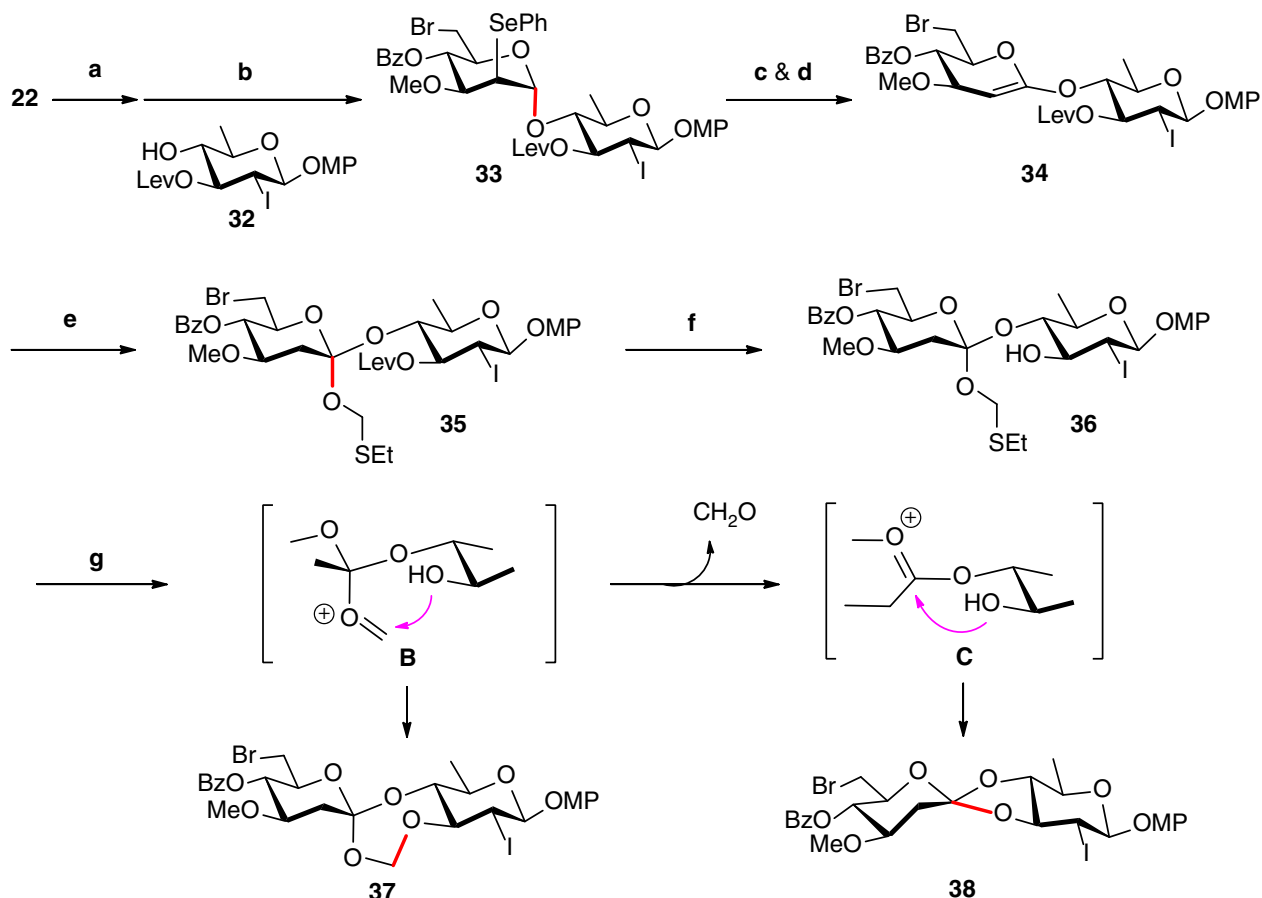

38

Figure 4 | Construction of the FABO motif with the natural configuration. Highlighted in red are the nascent glycosidic bonds. (a) DAST, THF, $-30{ }^{\circ} \mathrm{C}$ to $\mathrm{RT}$; (b) $\mathrm{SnCl}_{2}, \mathrm{Et}_{2} \mathrm{O}, 4 \AA \mathrm{MS}, \mathrm{O}^{\circ} \mathrm{C}$ to RT; $85 \%$ (for two steps); (c) $\mathrm{NaIO}_{4}, \mathrm{NaHCO}_{3}, \mathrm{MeOH}_{2} \mathrm{CH}_{2} \mathrm{Cl}_{2}, \mathrm{H}_{2} \mathrm{O}, \mathrm{RT}$, 99\%; (d) vinyl acetate, toluene, DIPA, $\mathrm{Mw}, 140{ }^{\circ} \mathrm{C}, 40 \mathrm{~min}, 92 \%$; (e) $\mathrm{EtSCH}_{2} \mathrm{OH}, \mathrm{DCCl}_{3}, \mathrm{Mw}, 10 \mathrm{~min}, 110^{\circ} \mathrm{C}, 81 \%$; (f) $\mathrm{H}_{2} \mathrm{NNH}_{2} \cdot \mathrm{H}_{2} \mathrm{O}$, pyridine, $\mathrm{HOAc}, 0^{\circ} \mathrm{C}$ to $\mathrm{RT}, 92 \%$; $(\mathbf{g}) \mathrm{BSP}, \mathrm{Tf}_{2} \mathrm{O}, \mathrm{DTBP}$, $5 \AA \mathrm{MS}, \mathrm{Et}_{2} \mathrm{O},-114{ }^{\circ} \mathrm{C}, 64 \%$ (for 37), 18\% (for 38). BSP, 1-benzenesulfinyl piperidine; DTBP, 2,6-di-tert-butylpyridine; Lev, levuloyl; Mw, microwave. 
temperature and shortening the reaction duration $\left(\mathrm{CDCl}_{3}\right.$, microwave $100^{\circ} \mathrm{C}, 1 \mathrm{~h}$ ), the addition of 34 and $\mathrm{PhSCH}_{2} \mathrm{OH}$ led to the desired orthoester in a good $70 \%$ yield but in a moderate diastereoselectivity of $1.4 / 1$. Modification of the reaction conditions by the addition of acidic promoters $(p-\mathrm{TsOH}$ or PPTS) or variation of solvent (toluene, $\mathrm{CH}_{2} \mathrm{Cl}_{2}$ or $\mathrm{CHCl}_{3}$ ) failed to improve the yield or the diastereoselectivity. Fortunately, replacement of $\mathrm{PhSCH}_{2} \mathrm{OH}$ with the more nucleophilic $\mathrm{EtSCH}_{2} \mathrm{OH}$, the addition with ketene acetal 34 under the optimal conditions $\left(\mathrm{CDCl}_{3}\right.$, microwave $\left.110^{\circ} \mathrm{C}, 10 \mathrm{~min}\right)$ furnished the desired orthoester 35 in $81 \%$ yield as a single $\alpha$-isomer. It should be noted that the replacement of $\mathrm{CDCl}_{3}$ with $\mathrm{CHCl}_{3}$ or toluene led to lower yields of $35(<65 \%)$. Selective removal of the 3-O-Lev group in $\mathbf{3 5}$ was achieved with $\mathrm{H}_{2} \mathrm{NNH}_{2} \cdot \mathrm{H}_{2} \mathrm{O}$ to provide orthoester 36 (92\%).

Treatment of ethylthiomethyl glycoside 36 with the mild promoters for glycosidation of thioglycosides (see Supplementary Table 2), such as MeOTf/TTBP, DMTST/TTBP, and $\mathrm{CuBr}_{2} /$ $\mathrm{Bu}_{4} \mathrm{NBr}^{49}$, failed to afford the seven-membered FABO derivative 37; instead, the five-membered orthoester 38 was isolated in high yield $(>80 \%)$ as a mixture of the two diastereoisomers. These results indicate again $(c f ., \mathbf{1 0} \rightarrow \mathbf{2 3 / 2 4})$ that the glycosyloxymethyl cation (B) generated via activation of the thioacetal could readily undergo decomposition to the glycosyl oxocarbenium (C) and formaldehyde; intramolecular addition of the proximal hydroxyl group to $\mathbf{C}$ led to the five-membered orthoester. Thus, a strong promoter which can activate the thioacetal under milder conditions might be able to allow the transient glycosyloxymethyl cation $\mathbf{B}$ to be captured by the hydroxyl group before decomposition. Using Crich's conditions $\left(\mathrm{Tf}_{2} \mathrm{O} / \mathrm{BSP} / \mathrm{TTBP}\right.$, $\left.-60^{\circ} \mathrm{C}, \mathrm{CH}_{2} \mathrm{Cl}_{2}\right)^{37}$, however, the five-membered orthoester 38 was again obtained nearly quantitatively as a mixture of the diastereoisomers. Encouragingly, when lowering the reaction temperature to $-78^{\circ} \mathrm{C}$, a trace amount of the desired sevenmembered FABO product 37 was detected. Optimizing along this direction, we finally managed to obtain the desired 37 in a satisfactory $64 \%$ yield in the presence of $\mathrm{Tf}_{2} \mathrm{O} / \mathrm{BSP} / \mathrm{DTBP}$ in $\mathrm{Et}_{2} \mathrm{O}$ at $-114^{\circ} \mathrm{C}$, whereas the five-membered orthoester 38 was isolated in $18 \%$ yield as a single diastereoisomer. Comparison of the NMR data of the present FABO disaccharide 37 with those of the previous 26 supported that we had fixed the desired configuration by the present approach.

Completion of the synthesis of periploside A (1). The transformations previously developed for the synthesis of $\mathrm{Cl}^{\prime \prime}$-epiperiploside A $(\mathbf{2 6} \rightarrow \mathbf{3 1}$, eight steps, $28 \%$ overall yield) were applied to the synthesis of periploside A (Fig. 5). Thus, FABO disaccharide 37 was subjected to selective cleavage of the anomeric MP group (with $\mathrm{Ag}(\mathrm{DPAH})_{2}, 91 \%$ ) and conversion into the trifluoroacetimidate donor $6(90 \%)$. Coupling of pregnane diol 7 with donor 6 under the similar conditions as that for $7+\mathbf{2 7} \rightarrow \mathbf{2 8}(85 \%, \beta / \alpha=3: 1)$ led to the corresponding disaccharide 39 in a similar yield $(87 \%)$ but much higher $\beta$ selectivity $(\beta / \alpha=6.1: 1)$. This result supports the previous assumption that the conformational restraint provided by the FABO motif affects the glycosidation transition state of the disaccharide. The bromide and iodide in 39 were removed cleanly with $\mathrm{Et}_{3} \mathrm{~B}$ / $\mathrm{Bu}_{3} \mathrm{SnH}$ (95\%); subsequent cleavage of the $4^{\prime}$-O-benzoyl group (NaOMe, HOMe, 96\%) provided the desired disaccharide acceptor 3. Condensation of $\mathbf{3}$ with tetrasaccharide donor $\mathbf{2}$ under the optimized conditions for $\mathbf{2 9}+\mathbf{2} \rightarrow \mathbf{3 0}(64 \%, \beta / \alpha=2.1: 1)$ afforded hexasaccharide 40 in a higher $80 \%$ (92\%, b.r.s.m.) yield and similar $\beta / \alpha$ ratio of $2: 1$. Finally, the terminal CA and TBS groups were removed successfully with thiourea and pyridinebuffered HF-pyridine, respectively, furnishing the target periploside A (1) (93\%, two steps). Gratifyingly, all the analytical data of $\mathbf{1}$ are in full agreement with those obtained for the natural product $^{1}$ (see Supplementary Table 3).

The immunosuppressive activities of the synthetic compounds. The synthetic periploside A (1) showed similar toxicity and
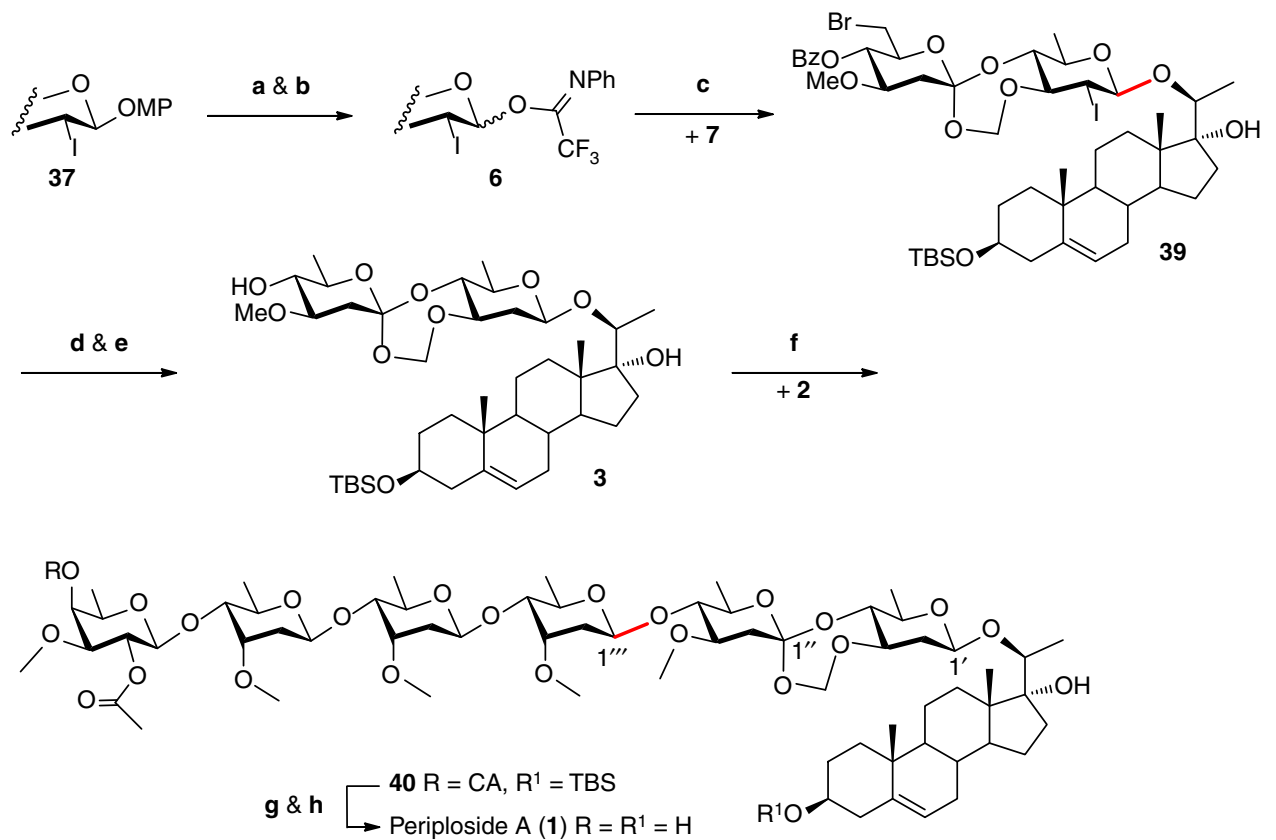

Figure 5 | Completion of the total synthesis of periploside $\mathbf{A}$ (1). Highlighted in red are the nascent glycosidic bonds. (a) $\mathrm{Ag}(\mathrm{DPAH})_{2}, \mathrm{CH} \mathrm{C}_{3} \mathrm{CN}, \mathrm{H}_{2} \mathrm{O}$, $0^{\circ} \mathrm{C}, 91 \%$; (b) $\mathrm{N}$-phenyl-trifluoroacetimidoyl chloride, $\mathrm{Cs}_{2} \mathrm{CO}_{3}, \mathrm{CH}_{2} \mathrm{Cl}_{2}, \mathrm{RT}, 90 \%$; (c) TBSOTf, $\mathrm{CH}_{2} \mathrm{Cl}_{2}, 5 \AA \mathrm{MS},-78^{\circ} \mathrm{C}, 87 \%, \beta / \alpha=6.1 / 1$; (d) $\mathrm{Et}{ }_{3} \mathrm{~B}$, $\mathrm{Bu}_{3} \mathrm{SnH}$, toluene, $\mathrm{RT}, 95 \%$; (e) $\mathrm{MeONa}, \mathrm{MeOH}, \mathrm{CH}_{2} \mathrm{Cl}_{2}, \mathrm{RT}$, 96\%; (f) $\mathrm{Ph}_{3} \mathrm{PAuOTf}\left(0.8\right.$ equiv), TTBP, $\mathrm{CH}_{2} \mathrm{Cl}_{2}, 4 \AA \mathrm{MS},-10{ }^{\circ} \mathrm{C}, 80 \%, \beta / \alpha=2 / 1 ;(\mathbf{g})$ thiourea, pyridine, $\mathrm{EtOH}, 80^{\circ} \mathrm{C}$; (h) $\mathrm{HF} \cdot \mathrm{py}$, pyridine, $\mathrm{THF}, 0^{\circ} \mathrm{C}$ to $\mathrm{RT}, 93 \%$ (for two steps). 
Table 1 | Inhibitory activity of periploside $A$ and analogues against T-lymphocyte proliferation*.

\begin{tabular}{|c|c|c|c|}
\hline Compound & $\mathrm{CC}_{50}(\mu \mathrm{M})$ & $I_{50}(\mu M)$ & SI \\
\hline Periploside A (1) & $2.10 \pm 0.32$ & $0.17 \pm 0.04$ & 12 \\
\hline $\mathrm{Cl}^{\prime \prime}$-epi-periploside $\mathrm{A}(\mathbf{3 1})$ & $1.58 \pm 0.19$ & $0.41 \pm 0.15$ & 3.9 \\
\hline$C 1^{\prime \prime \prime}$-epi-periploside $\mathrm{A}(\mathbf{4 1})$ & $11.40 \pm 3.66$ & $1.96 \pm 0.43$ & 5.8 \\
\hline Disaccharide $\mathbf{4 2}$ & $12.80 \pm 0.52$ & $6.20 \pm 3.20$ & 2.1 \\
\hline Disaccharide $\mathbf{4 3}$ & $27.70 \pm 6.61$ & $3.70 \pm 2.25$ & 7.5 \\
\hline
\end{tabular}

*See Supplementary Methods and Supplementary Figs 62 and 63 for details.

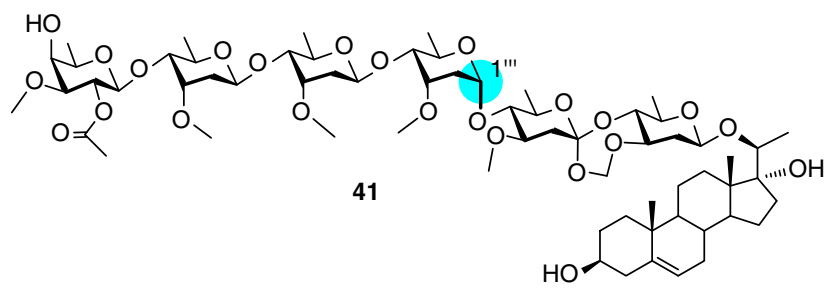

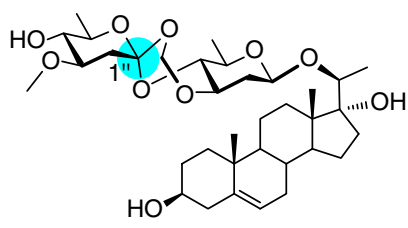

42

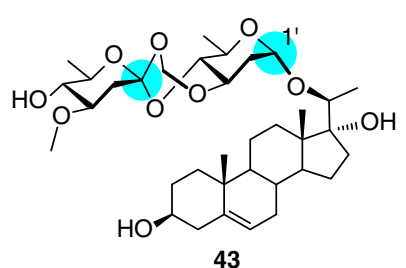

43
Figure 6 | Synthetic analogues of periplosides. Shadowed in pale blue are the carbon centres with opposite configurations to those in the nature product.

activity as the natural product against $\mathrm{T}$-lymphocyte and their proliferation induced by Con $\mathrm{A}^{5,6}$. The $\mathrm{Cl}^{\prime \prime}$-epimer (31) which has the opposite configuration at the FABO motif as in periploside $\mathrm{A}$ was also found active $\left(\mathrm{IC}_{50}=0.41 \mu \mathrm{M}\right)$, although being $\sim 2.4$-fold less potent than the natural product (Table 1 ). The $\mathrm{C1}^{\prime \prime \prime}$-epimer of periploside $\mathrm{A}$ (41) was also active $\left(\mathrm{IC}_{50}=1.96 \mu \mathrm{M}\right) \quad$ (Fig. 6). Interestingly, disaccharide 42, with the tetrasaccharide in $\mathbf{3 1}$ being truncated, still had certain activity $\left(\mathrm{IC}_{50}=6.20 \mu \mathrm{M}\right)$; and its $\alpha$-anomer 43 even showed a higher activity $\left(\mathrm{IC}_{50}=3.70 \mu \mathrm{M}\right)$. Previous assays have demonstrated that reductive cleavage of the formyl acetal in the FABO motif in periploside A abolished the activity completely ${ }^{6}$. Taken together, it demonstrates that the chemical connection of the FABO motif, rather than the stereochemistry, has a critical role in the immunosuppressive activities of periplosides. The capability of releasing a formylaldehyde might be taken into account in the future researches into the mechanism of action of this unique type of compounds.

\begin{abstract}
Methods
General methods. All the reactions were carried out under nitrogen or argon with anhydrous solvents in flame-dried glassware, unless otherwise noted. All the glycosylation reactions were performed in the presence of 4 or $5 \AA$ MS, which were flame-dried immediately before use in the reaction under high vacuum. Glycosylation solvents were dried using a solvent purification system and used directly without further drying. The chemicals used were reagent grade as supplied, except where noted. For details of the synthetic procedures and the characterization data of compounds, see Supplementary Methods. For ${ }^{1} \mathrm{H}$ and ${ }^{13} \mathrm{C}$ NMR spectra of the compounds prepared in this study, see Supplementary Figs 1-58.
\end{abstract}

Synthesis of acetal glycoside 24. To a solution of sugar alcohol $11(620 \mathrm{mg}$, $1.47 \mathrm{mmol})$ in $\mathrm{CH}_{2} \mathrm{Cl}_{2}(5 \mathrm{ml})$ was added acid-washed $3 \AA \mathrm{MS}$ at RT. After stirring for $30 \mathrm{~min}$ at RT, NIS $(142 \mathrm{mg}, 0.63 \mathrm{mmol})$ and TfOH $(2.6 \mu \mathrm{l}, 0.029 \mathrm{mmol})$ were added to the mixture at $-30^{\circ} \mathrm{C}$, followed by the addition of a solution of phenylthiomethyl glycoside 10 (183 $\mathrm{mg}, 0.29 \mathrm{mmol})$ in $\mathrm{CH}_{2} \mathrm{Cl}_{2}(3 \mathrm{ml})$ via a syringe pump. The reaction mixture was stirred at $-30^{\circ} \mathrm{C}$ for $1 \mathrm{~h}$. When TLC showed the donor 10 had been consumed, saturated aqueous $\mathrm{NaHCO}_{3}$ was added at $0{ }^{\circ} \mathrm{C}$. The mixture was filtered. The filtrate was washed with a solution of $\mathrm{NaS}_{2} \mathrm{O}_{3}$ and brine, respectively, and was then dried over $\mathrm{Na}_{2} \mathrm{SO}_{4}$ and concentrated. The residue was purified by flash chromatography (petroleum ether $/ \mathrm{CH}_{2} \mathrm{Cl}_{2} / \mathrm{EtOAc}=8: 1: 1$ ) to afford $24(206 \mathrm{mg}, 75 \%)$ and glycoside $23(53 \mathrm{mg}, 20 \%)$ as syrups.

Synthesis of FABO disaccharide 25. To a solution of acetal glycoside $\mathbf{9}(187 \mathrm{mg}$, $0.24 \mathrm{mmol})$ in $\mathrm{MeOH} / \mathrm{CH}_{2} \mathrm{Cl}_{2} / \mathrm{H}_{2} \mathrm{O}(3 \mathrm{ml} / 2 \mathrm{ml} / 1 \mathrm{ml})$ were added $\mathrm{NaIO}_{4}(507 \mathrm{mg}$, $2.37 \mathrm{mmol})$ and $\mathrm{NaHCO}_{3}(159 \mathrm{mg}, 1.90 \mathrm{mmol})$ at RT. After stirring for $3 \mathrm{~h}$, the mixture was diluted with $\mathrm{CH}_{2} \mathrm{Cl}_{2}$, washed with saturated $\mathrm{NH}_{4} \mathrm{Cl}$ solution and brine, respectively, and was then dried over $\mathrm{Na}_{2} \mathrm{SO}_{4}$ and concentrated. The resultant selenoxide was azeotroped with toluene $(3 \times 5 \mathrm{ml})$ and dried under high vacuum for $2 \mathrm{~h}$ to afford a white solid $(190 \mathrm{mg}, 99 \%)$. The above selenoxide (125 mg, $0.155 \mathrm{mmol}$ ) was dissolved in toluene $(6 \mathrm{ml})$. Diisopropylamine $(3 \mathrm{ml})$ and vinyl acetate $(6 \mathrm{ml})$ were added, and the reaction was conducted under microwave at $145^{\circ} \mathrm{C}$ for $20 \mathrm{~min}$. The mixture was cooled to $\mathrm{RT}$ and concentrated. The residue was purified by flash chromatography on silica gel (petroleum ether/EtOAc $=1.5: 1$ ) to afford $25(83 \mathrm{mg}, 85 \%)$ as a colourless syrup.

Synthesis of $\boldsymbol{\alpha}$-disaccharide 33. To a solution of lactol $22(603 \mathrm{mg}, 1.21 \mathrm{mmol})$ in THF $(10 \mathrm{ml})$ was added DAST $(0.44 \mathrm{ml}, 3.63 \mathrm{mmol})$ at $-30^{\circ} \mathrm{C}$. After stirring for $1.5 \mathrm{~h}$ while warming to $\mathrm{RT}$, a saturated $\mathrm{NaHCO}_{3}$ solution was added slowly to the mixture. The resulting mixture was extracted with $\mathrm{CH}_{2} \mathrm{Cl}_{2}$. The combined organic layer was washed with brine, dried over $\mathrm{Na}_{2} \mathrm{SO}_{4}$ and concentrated. The crude glycosyl fluoride was azeotroped with toluene $(3 \times 5 \mathrm{ml})$. After drying under high vacuum for $2 \mathrm{~h}$, the above product was dissolved in $\mathrm{Et}_{2} \mathrm{O}(10 \mathrm{ml}), 4 \AA \mathrm{MS}(1.2 \mathrm{~g})$ and sugar alcohol $32(330 \mathrm{mg}, 0.69 \mathrm{mmol})$ were added and the reaction mixture was stirred at $0^{\circ} \mathrm{C}$ for $30 \mathrm{~min}$. $\mathrm{SnCl}_{2}(235 \mathrm{mg}, 1.24 \mathrm{mmol})$ was added in one portion and the reaction mixture was allowed to warm to RT and stirred for $4 \mathrm{~h}$. The mixture was quenched with $\mathrm{Et}_{3} \mathrm{~N}(1 \mathrm{ml})$ and filtered. The solution was diluted with EtOAc and washed with water. The water layer was extracted with EtOAc twice. The combined organic layer was washed with saturated $\mathrm{NaHCO}_{3}$ solution and brine, respectively, and was then dried over $\mathrm{Na}_{2} \mathrm{SO}_{4}$ and concentrated. The residue was purified by flash chromatography (petroleum ether/EtOAc $=4: 1$ ) to afford 33 (560 mg, 85\%) as a colourless syrup.

Synthesis of ketene acetal 34. To a solution of $33(248 \mathrm{mg}, 0.26 \mathrm{mmol})$ in $\mathrm{MeOH} / \mathrm{CH}_{2} \mathrm{Cl}_{2} / \mathrm{H}_{2} \mathrm{O}(3 \mathrm{ml} / 2 \mathrm{ml} / 1 \mathrm{ml})$ were added $\mathrm{NaIO}_{4}(552 \mathrm{mg}, 2.58 \mathrm{mmol})$ and $\mathrm{NaHCO}_{3}(173 \mathrm{mg}, 2.06 \mathrm{mmol})$ at RT. After stirring for $12 \mathrm{~h}$ at RT, the mixture was diluted with $\mathrm{CH}_{2} \mathrm{Cl}_{2}$, and washed with saturated $\mathrm{NH}_{4} \mathrm{Cl}$ solution and brine, respectively. The organic layer was dried over $\mathrm{Na}_{2} \mathrm{SO}_{4}$ and concentrated. The crude selenoxide was azeotroped with toluene $(3 \times 5 \mathrm{ml})$ and dried under high vacuum for $2 \mathrm{~h}$ to afford a colourless syrup ( $251 \mathrm{mg}, 99 \%)$. The above selenoxide (104 mg $0.11 \mathrm{mmol})$ was dissolved in toluene $(2 \mathrm{ml})$. Diisopropylamine $(1 \mathrm{ml})$ and vinyl acetate $(2 \mathrm{ml})$ were added. The reaction was conducted under microwave at $140^{\circ} \mathrm{C}$ for $40 \mathrm{~min}$. The mixture was cooled to RT and concentrated. The residue was purified by flash chromatography (petroleum ether/EtOAc $=5: 1$, containing $1 \%$ $\left.\mathrm{Et}_{3} \mathrm{~N}\right)$ to afford $34(85 \mathrm{mg}, 92 \%)$ as a colourless syrup.

Synthesis of orthoester 35. To a solution of $34(75 \mathrm{mg}, 0.093 \mathrm{mmol})$ in $\mathrm{CDCl}_{3}(3 \mathrm{ml})$ was added $\mathrm{EtSCH} \mathrm{H}_{2} \mathrm{OH}(0.05 \mathrm{ml})$ at RT. The reaction was conducted under microwave at $110^{\circ} \mathrm{C}$ for $10 \mathrm{~min}$. The mixture was cooled to RT and concentrated. The residue was purified by flash chromatography (petroleum ether/EtOAc $=5: 1$, containing $\left.1 \% \mathrm{Et}_{3} \mathrm{~N}\right)$ to afford $35(67 \mathrm{mg}, 81 \%)$ as a colourless syrup.

Synthesis of orthoester 36 . To a solution of $35(110 \mathrm{mg}, 0.120 \mathrm{mmol})$ in pyridine/HOAc $(3 \mathrm{ml} / 2 \mathrm{ml})$ was added $\mathrm{H}_{2} \mathrm{NNH}_{2} \mathrm{H}_{2} \mathrm{O}(0.10 \mathrm{ml}, 1.60 \mathrm{mmol})$ at $0{ }^{\circ} \mathrm{C}$ After stirring at RT for $5 \mathrm{~h}$, the mixture was diluted with $\mathrm{CH}_{2} \mathrm{Cl}_{2}$, and washed with ice water and then with a saturated $\mathrm{NaHCO}_{3}$ solution and brine, respectively. The organic layer was dried over $\mathrm{Na}_{2} \mathrm{SO}_{4}$ and concentrated. The residue was purified by flash chromatography (petroleum ether/EtOAc $=5: 1$, containing $1 \% \mathrm{Et}_{3} \mathrm{~N}$ ) to afford 36 (90 $\mathrm{mg}, 92 \%)$ as a colourless syrup.

Synthesis of FABO disaccharide 37. To a solution of $\mathbf{3 6}(19.1 \mathrm{mg}, 0.024 \mathrm{mmol})$ in $\mathrm{Et}_{2} \mathrm{O}(3 \mathrm{ml})$ were added BSP $(8.2 \mathrm{mg}, 0.036 \mathrm{mmol}), 2,6$-di-tert-butylpyridine $(16.0 \mu \mathrm{l}$, $0.072 \mathrm{mmol}$ ) and $5 \AA \mathrm{MS}$ at RT. After stirring at $-114^{\circ} \mathrm{C}$ (liq. $\mathrm{N}_{2}$-EtOH) for $20 \mathrm{~min}, \mathrm{Tf}_{2} \mathrm{O}(6.0 \mu \mathrm{l}, 0.036 \mathrm{mmol})$ was added to the mixture. The mixture was stirred at $-114^{\circ} \mathrm{C}$ for $1 \mathrm{~h}$, and was then warmed to RT and filtered. The filtrate was washed with a saturated aqueous $\mathrm{NaHCO}_{3}$ solution and brine, respectively, and was then dried over $\mathrm{Na}_{2} \mathrm{SO}_{4}$ and concentrated. The residue was purified by flash chromatography on silica gel (petroleum ether/EtOAc $=5: 1)$ to afford $37(11.3 \mathrm{mg}$, $64 \%)$ and the five-membered orthoester $38(3.0 \mathrm{mg}, 18 \%)$ as colourless syrups. 
Synthesis of FABO disaccharide trifluoroacetimidate 6. To a solution of p-methoxyphenyl glycoside $37(36 \mathrm{mg}, 0.049 \mathrm{mmol})$ in $\mathrm{CH}_{3} \mathrm{CN} / \mathrm{H}_{2} \mathrm{O}(3 \mathrm{ml} / 3 \mathrm{ml})$ was added $\mathrm{Ag}(\mathrm{DPAH})_{2}(79 \mathrm{mg}, 0.17 \mathrm{mmol})$ at $0^{\circ} \mathrm{C}$. After stirring for $30 \mathrm{~min}$ at this temperature, the mixture was filtered. The filtrate was diluted with $\mathrm{CH}_{2} \mathrm{Cl}_{2}$, washed with saturated $\mathrm{NaHCO}_{3}$ solution and brine, respectively, and was then dried over $\mathrm{Na}_{2} \mathrm{SO}_{4}$ and concentrated. The residue was purified by flash chromatography (petroleum ether/EtOAc $=3: 1$ ) to yield the corresponding hemiacetal $(28 \mathrm{mg}, 91 \%)$ as a colourless syrup. To a solution of the hemiacetal $(29 \mathrm{mg}$, $0.046 \mathrm{mmol})$ in $\mathrm{CH}_{2} \mathrm{Cl}_{2}(3 \mathrm{ml})$ were added $\mathrm{Cs}_{2} \mathrm{CO}_{3}(75 \mathrm{mg}, 0.23 \mathrm{mmol})$ and $\mathrm{N}-$ phenyl-2,2,2-trifluoroacetimidoyl chloride $(14 \mu \mathrm{l}, 0.14 \mathrm{mmol})$ at RT. After stirring for $3 \mathrm{~h}$, the mixture was filtered. The filtrate was evaporated in vacuo to give a residue, which was subjected to chromatography on Davisil silica $(\mathrm{pH}=7.0$, petroleum ether/EtOAc, 5:1) to give $6(33 \mathrm{mg}, 90 \%)$ as a colourless syrup. This compound was used directly without further characterization.

Synthesis of pregnane $\boldsymbol{\beta}$-disaccharide 39. To a solution of imidate $\mathbf{6}(33.0 \mathrm{mg}$, $0.041 \mathrm{mmol})$ and pregnane diol $7(15.6 \mathrm{mg}, 0.035 \mathrm{mmol})$ in $\mathrm{CH}_{2} \mathrm{Cl}_{2}(3 \mathrm{ml})$ was added $5 \AA \mathrm{MS}$ at RT. After stirring at $-78^{\circ} \mathrm{C}$ for $30 \mathrm{~min}$, TBSOTf $(1.2 \mu \mathrm{l}$, $0.0052 \mathrm{mmol}$ ) was added to the mixture. After stirring for $6 \mathrm{~h}$ at this temperature, $\mathrm{Et}_{3} \mathrm{~N}$ was added to quench the reaction. The resulting mixture was filtered. The filtrate was evaporated in vacuo to give a residue, which was purified by flash chromatography (petroleum ether $\left./ \mathrm{CH}_{2} \mathrm{Cl}_{2} / \mathrm{EtOAc}=10: 5: 1\right)$ to afford $39(27.6 \mathrm{mg}$, $75 \%)$ and its $\alpha$-anomer ( $4.5 \mathrm{mg}, 12 \%$ ) as white solids.

Synthesis of pregnane disaccharide 3. To a solution of $39(21.0 \mathrm{mg}, 0.020 \mathrm{mmol})$ in toluene $(2 \mathrm{ml})$ were added $\mathrm{Bu}_{3} \mathrm{SnH}(32 \mu \mathrm{l}, 0.12 \mathrm{mmol})$ and $\mathrm{Et}_{3} \mathrm{~B}(12 \mu \mathrm{l}$, $0.012 \mathrm{mmol}$ ) at $0{ }^{\circ} \mathrm{C}$. After stirring for $1 \mathrm{~h}$ at $\mathrm{RT}$, the mixture was concentrated in vacuo. The residue was purified by flash chromatography (petroleum ether/ $\mathrm{EtOAc}=5: 1)$ to afford the corresponding $2^{\prime}, 6^{\prime \prime}$-deoxy derivative $(16.5 \mathrm{mg}, 97 \%)$ as a white solid (see Supplementary Methods). To a solution of this compound $(16.5 \mathrm{mg}, 0.019 \mathrm{mmol})$ in $\mathrm{CH}_{2} \mathrm{Cl}_{2} / \mathrm{MeOH}(1.5 \mathrm{ml} / 1.5 \mathrm{ml})$ was added $\mathrm{NaOMe}$ (20 $\mathrm{mg}, 0.37 \mathrm{mmol}$ ) at RT. After stirring for $40 \mathrm{~h}$, the mixture was filtered through silica gel. The filtrate was evaporated in vacuo to give a residue, which was purified by flash chromatography (petroleum ether/EtOAc $=2: 1)$ to afford $3(14.0 \mathrm{mg}, 97 \%)$ as a white solid.

Synthesis of pregnane hexasaccharide 40 . To a solution of tetrasaccharide ortho-cyclopropylethynylbenzoate $2(22.3 \mathrm{mg}, 0.025 \mathrm{mmol})$, pregnane disaccharide $3(8.0 \mathrm{mg}, 0.011 \mathrm{mmol})$ and 2,4,6-tri-tert-butylpyrimidine (TTBP) $(4.0 \mathrm{mg}$, $0.016 \mathrm{mmol})$ in $\mathrm{CH}_{2} \mathrm{Cl}_{2}(2 \mathrm{ml})$ was added $4 \AA \mathrm{MS}$ at RT. After stirring for $30 \mathrm{~min}$ at $-20^{\circ} \mathrm{C}$, a solution of $\mathrm{PPh}_{3} \mathrm{AuOTf}$ in $\mathrm{CH}_{2} \mathrm{Cl}_{2}(0.05 \mathrm{ml}, 0.1 \mathrm{M})$ was added to the mixture. The mixture was stirred for $2 \mathrm{~h}$ while warming to $-10^{\circ} \mathrm{C}$, then another portion of $\mathrm{PPh}_{3} \mathrm{AuOTf}$ in $\mathrm{CH}_{2} \mathrm{Cl}_{2}(0.05 \mathrm{ml}, 0.1 \mathrm{M})$ was added to the mixture. After stirring for $4 \mathrm{~h}$ at $-10^{\circ} \mathrm{C} \mathrm{Et}_{3} \mathrm{~N}$ was added to quench the reaction. The resulting mixture was filtered and concentrated. The residue was purified by flash chromatography (petroleum ether $\left./ \mathrm{CH}_{2} \mathrm{Cl}_{2} / \mathrm{EtOAc}=1: 1: 1\right)$ to afford $\mathbf{4 0}(8.3 \mathrm{mg}, 53 \%)$, its $\alpha$-anomer (4.2 $\mathrm{mg}, 27 \%$ ) as white foams, and recovered $3(1.0 \mathrm{mg}, 13 \%)$.

Synthesis of Periploside A 1. To a solution of $\mathbf{4 0}(4.7 \mathrm{mg}, 3.2 \mu \mathrm{mol})$ in pyridine/ EtOH $(1.0 \mathrm{ml} / 1.0 \mathrm{ml})$ was added thiourea $(10 \mathrm{mg}, 0.13 \mathrm{mmol})$ at RT. After stirring for $2 \mathrm{~h}$ at $80^{\circ} \mathrm{C}$, the mixture was concentrated in vacuo to give a residue, which was purified by flash chromatography $\left(\mathrm{CHCl}_{3} / \mathrm{MeOH}=30: 1\right)$ to afford a colourless syrup. The syrup was dissolved in THF/pyridine $(1.5 \mathrm{ml} / 0.75 \mathrm{ml})$. HF-py (70\% HF in pyridine, $0.10 \mathrm{ml}$ ) was added dropwise at $0^{\circ} \mathrm{C}$. After stirring for $40 \mathrm{~h}$ at RT, a saturated $\mathrm{NaHCO}_{3}$ solution was added slowly to the mixture at RT. The resulting mixture was diluted with $\mathrm{CH}_{2} \mathrm{Cl}_{2}$, washed with saturated $\mathrm{NaHCO}_{3}$ solution and was then extracted with $\mathrm{CH}_{2} \mathrm{Cl}_{2}$ twice. The combined organic layer was washed with brine, dried over $\mathrm{Na}_{2} \mathrm{SO}_{4}$ and concentrated. The residue was purified by flash chromatography $\left(\mathrm{CHCl}_{3} / \mathrm{MeOH}=30: 1\right)$ to afford periploside A (1) $(3.8 \mathrm{mg}, 93 \%)$ as a white foam.

\section{References}

1. Oshima, Y., Hirota, T. \& Hikino, H. Periplosides A, B and C, steroidal glycosides of Periploca sepium root barks. Heterocycles 26, 2093-2098 (1987).

2. Itokawa, H. et al. Studies on chemical constituents of antitumor fraction from Periploca sepium. II. Structures of new pregnane glycosides, periplocosides A, B and C. Chem. Pharm. Bull. 36, 982-987 (1988).

3. Itokawa, H. et al. Studies on chemical constituents of antitumor fraction from Periploca sepium. IV. Structures of new pregnane glycosides, periplocosides D, E, L and M. Chem. Pharm. Bull. 36, 2084-2089 (1988).

4. Itokawa, H. et al. Studies on chemical constituents of antitumor fraction from Periploca sepium. V. Structures of new pregnane glycosides, periplocosides J, K, F and O. Chem. Pharm. Bull. 36, 4441-4446 (1988).

5. Feng, J. Q. et al. Immunosuppressive pregnane glycosides from Periploca sepium and Periploca forrestii. Phytochemistry 69, 2716-2723 (2008).
6. Wang, L.-Y. et al. Structural revision of periplocosides and periperoxides, natural immunosuppressive agents from the genus Periploca. Phytochemistry 72, 2230-2236 (2011).

7. Wang, L.-Y. et al. Corrigendum to "Structural revision of periplocosides and periperoxides, natural immunosuppressive agents from the genus Periploca". Phytochemistry 95, 445 (2013).

8. Zhu, Y.-N. et al. Periplocoside E, an effective compound from Periploca sepium Bge, inhibited $\mathrm{T}$ cell proliferation in vitro and in vivo. J. Pharmacol. Exp. Ther. 316, 662-669 (2006).

9. Zhu, Y.-N. et al. Periplocoside E inhibits experimental allergic encephalomyelitis by suppressing IL-12-dependent CCR5 expression and IFN- $\gamma$-dependent CXCR3 expression in T lymphocytes. J. Pharmacol. Exp. Ther. 318, 1153-1162 (2006).

10. Zhao, W. et al. Use of periplocoside A and periplocoside E for preparing immunosuppressants used for preventing and treating autoimmune diseases such as rheumatoid arthritis, autoimmune hepatitis and insulin-dependent diabetes. WO2007036113-A1; CN1939324-A; CN1939324-B.

11. Jiangsu New Medical College. Dictionary of Chinese Herb Medicines 1683 and 2388A (Shanghai Scientific and Technologic Press, 1998).

12. Mann, J. Natural products as immunosuppressive agents. Nat. Prod. Rep. 18, 417-430 (2001).

13. Yu, B., Sun, J. \& Yang, X. Assembly of naturally occurring glycosides, evolved tactics, and glycosylation methods. Acc. Chem. Res. 45, 1227-1236 (2012).

14. Borovika, A. \& Nagorny, P. Recent advances in the synthesis of natural 2-deoxy- $\beta$-glycosides. J. Carbohydr. Chem. 31, 255-283 (2012).

15. Ma, Y., Li, Z., Shi, H., Zhang, J. \& Yu, B. Assembly of digitoxin by gold(I)catalyzed glycosidation of glycosyl o-alkynylbenzoates. J. Org. Chem. 76, 9748-9756 (2011).

16. Zhang, J., Shi, H., Ma, Y. \& Yu, B. Expeditious synthesis of saponin P57, an appetite suppressant from Hoodia plants. Chem. Commun. 48, 8679-8681 (2012).

17. Zhang, S., Ma, Y., Ma, J., Yu, B. \& Xie, X. Molecular matchmaking between the popular 'weight loss' herb Hoodia gordonii and GPR119, a potential drug target for metabolic disorders. Proc. Natl Acad. Sci. USA 111, 14571-14576 (2014).

18. Tang, Y., Li, J., Zhu, Y., Li, Y. \& Yu, B. Mechanistic insights into the gold(I)catalyzed activation of glycosyl ortho-alkynylbenzoates for glycosidation. J. Am Chem. Soc. 135, 18396-18405 (2013).

19. Yu, B. \& Sun, J. Glycosylation with glycosyl $N$-phenyltrifluoroacetimidates (PTFAI) and a perspective of the future development of new glycosylation methods. Chem. Commun. 46, 4668-4679 (2010).

20. Roush, W. R. \& Bennett, C. E. A highly stereoselective synthesis of 2-deoxy- $\beta$ glycosides using 2-deoxy-2-iodo-glucopyranosyl acetate donors. J. Am. Chem. Soc. 121, 3541-3542 (1999).

21. Crich, D. \& Yang, F. Phenylthiomethyl glycosides: convenient synthons for the formation of azidomethyl and glycosylmethyl glycosides and their derivatives. Angew. Chem. Int. Ed. 48, 8896-8899 (2009).

22. Jaurand, G., Beau, J.-M. \& Sinaÿ, P. Organoselenium chemistry: stereoselective conversion of glycals into anomeric spiro-orthoesters using a glycosyloxyselenation-oxidation elimination sequence. J. Chem. Soc. Chem. Commun. 701-703 (1982).

23. Nicolaou, K. C. et al. Total synthesis of everninomicin 13,384-1-part 2: synthesis of the $\mathrm{FGHA}_{2}$ fragment. Angew. Chem. Int. Ed. 38, 3340-3345 (1999)

24. Nicolaou, K. C. et al. 1,2-Seleno migrations in carbohydrate chemistry: solution and solid-phase synthesis of 2-deoxy glycosides, orthoesters, and allyl orthoesters. Angew. Chem. Int. Ed. 39, 1089-1093 (2000).

25. Zhou, M. \& O'Doherty, G. A. A stereoselective synthesis of digitoxin and digitoxigen mono- and bisdigitoxoside from digitoxigenin via a palladiumcatalyzed glycosylation. Org. Lett. 8, 4339-4342 (2006).

26. Kadota, I. \& Yamamoto, Y. Stereocontrolled total synthesis of hemibrevetoxin B. J. Org. Chem. 63, 6597-6606 (1998).

27. Tang, Y. \& Yu, B. Identification of (phosphine)gold(I) hydrates and their equilibria in wet solutions. RSC Adv. 2, 12686-12689 (2012).

28. Noshita, T., Sugiyama, T., Kitazumi, Y. \& Oritani, T. Phenolic Ferrier reaction and its application to the natural product synthesis. Tetrahedron Lett. 35, 8259-8262 (1994).

29. Horito, S., Asano, K., Umemura, K., Hashimoto, H. \& Yoshimura, J. A new synthesis of 2,3,4,6-tetra-O-benzyl-D-glucopyranosylidene acetals, using trimethylsilyl trifluoromethanesulfonate as the catalyst. Carbohydr. Res. 121, 175-185 (1983).

30. Ohtake, H., Ichiba, N. \& Ikegami, S. Synthesis and structure of 4-O,6-Oglycosylidene glycosides. J. Org. Chem. 65, 8164-8170 (2000).

31. Durham, T. B., Blanchard, N., Savall, B. M., Powell, N. A. \& Roush, W. R. Total synthesis of formamicin. J. Am. Chem. Soc. 126, 9307-9317 (2004).

32. Praly, J.-P. \& Descotes, G. Photocyclisation d'hydroxyalkyl glycosides en orthoesters glycosidiques. Tetrahedron Lett. 23, 849-852 (1982).

33. Martín, A., Pérez-Martín, I., Quintanal, L. M. \& Suárez, E. Intramolecular 1,8versus 1,6 -hydrogen atom transfer between pyranose units in $\alpha(1 \rightarrow 4)$ - 
disaccharide model promoted by alkoxyl radicals. Conformational and stereochemical requirements. Org. Lett. 9, 1785-1788 (2007).

34. Nicolaou, K. C. et al. Total synthesis of apoptolidin: construction of enantiomerically pure fragments. J. Am. Chem. Soc. 125, 15433-15442 (2003).

35. Lian, G., Zhang, X. \& Yu, B. Thioglycosides in carbohydrate research. Carbohydr. Res. doi:10.1016/j.carres.2014.06.009 (in the press).

36. Sasaki, M. \& Tachibana, K. An efficient and stereocontrolled synthesis of the nephritogenoside core structure. Tetrahedron Lett. 32, 6873-6876 (1991).

37. Crich, D. \& Smith, M. 1-Benzenesulfinyl piperidine/trifluoromethanesulfonic anhydride: a potent combination of shelf-stable reagents for the low-temperature conversion of thioglycosides to glycosyl triflates and for the formation of diverse glycosidic linkages. J. Am. Chem. Soc. 123, 9015-9020 (2001).

38. Fügedi, P. \& Garegg, P. J. A novel promoter for the efficient construction of 1,2-trans linkages in glycoside synthesis, using thioglycosides as glycosyl donors. Carbohydr. Res. 149, C9-C12 (1986).

39. Ishiwata, A., Sakurai, A., Nishimiya, Y., Tsuda, S. \& Ito, Y. Synthetic study and structural analysis of the antifreeze agent xylomannan from Upis ceramboides. J. Am. Chem. Soc. 133, 19524-19535 (2011).

40. Konradsson, P., Udodong, U. E. \& Fraser-Reid, B. Iodonium promoted reactions of disarmed thioglycosides. Tetrahedron Lett. 31, 4313-4316 (1990).

41. Schmidt, R. R. \& Toepfer, A. Glycosylation with highly reactive glycosyl donors: efficiency of the inverse procedure. Tetrahedron Lett. 32, 3353-3356 (1991).

42. Yang, M. T. \& Woerpel, K. A. The effect of electrostatic interactions on conformational equilibria of multiply substituted tetrahydropyran oxocarbenium ions. J. Org. Chem. 74, 545-553 (2009).

43. Chamberland, S., Ziller, J. W. \& Woerpel, K. A. Structural evidence that alkoxy substituents adopt electronically preferred pseudoaxial orientations in sixmembered ring dioxocarbenium ions. J. Am. Chem. Soc. 127, 5322-5323 (2005).

44. Miura, K. et al. Triethylborane-induced hydrodehalogenation of organic halides by tin hydrides. Bull. Chem. Soc. Jpn 62, 143-147 (1989).

45. Zhu, Y. \& Yu, B. Characterization of the isochromen-4-yl-gold(I) intermediate in the gold(I)-catalyzed glycosidation of glycosyl ortho-alkynylbenzoates and enhancement of the catalytic efficiency thereof. Angew. Chem. Int. Ed. 50, 8329-8332 (2011)

46. Nie, S., Li, W. \& Yu, B. Total synthesis of nucleoside antibiotic A201A. J. Am. Chem. Soc. 136, 4157-4160 (2014).

47. Cook, A. F. \& Maichuk, D. T. Use of chloroacetic anhydride for the protection of nucleoside hydroxyl groups. J. Org. Chem. 35, 1940-1943 (1970).
48. Adam, W. \& Wang, X. E/Z Isomerization, solvolysis, addition, and cycloaddition reactions of $(E)$-tert-butylketene methyl tert-butyldimethylsilyl acetal. J. Org. Chem. 56, 7244-7250 (1991).

49. Sawada, D. \& Ito, Y. A new method for formacetal linkage formation: protection of alcohols, phenols and carboxylic acids. Tetrahedron Lett. 42, 2501-2504 (2001).

\section{Acknowledgements}

This work is financially supported by the National Natural Science Foundation of China (21432012 and 91213301), the Ministry of Sciences and Technology of China (2012ZX09502-002) and the E-Institute of Shanghai Municipal Education Commission (E09013). We are grateful to Professor Wei-Min Zhao for providing an authentic sample of the natural product periploside A and to Professor Tian-Xiang Li for providing a photo of the plant.

\section{Author contributions}

X.Z. and B.Y. conceived the synthetic route. X.Z. conducted the synthetic work. Y.Z. and J.Z. conducted bioassay. B.Y. and X.Z. wrote the manuscript.

\section{Additional information}

Supplementary Information accompanies this paper at http://www.nature.com/ naturecommunications

Competing financial interests: The authors declare no competing financial interests.

Reprints and permission information is available online at http://npg.nature.com/ reprintsandpermissions/

How to cite this article: Zhang, X. et al. Total synthesis of periploside A, a unique pregnane hexasaccharide with potent immunosuppressive effects. Nat. Commun. 6:5879 doi: $10.1038 /$ ncomms6879 (2015).

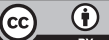

This work is licensed under a Creative Commons Attribution 4.0 International License. The images or other third party material in this article are included in the article's Creative Commons license, unless indicated otherwise in the credit line; if the material is not included under the Creative Commons license, users will need to obtain permission from the license holder to reproduce the material To view a copy of this license, visit http://creativecommons.org/licenses/by/4.0/ 